\title{
POSSIBLE APPROACH TO PROTECTION OF CRITICAL INFRASTRUCTURE ELEMENT IN TRANSPORT SECTOR
}

\author{
Dagmar Vidrikova \\ University of Žilina in Žilina, Faculty of Special Engineering, Žilina, Slovakia \\ Kamil Boc \\ University of Žilina in Žilina, Faculty of Special Engineering, Žilina, Slovakia \\ Katarina Škatuliakova \\ University of Žilina in Žilina, Faculty of Special Engineering, Žilina, Slovakia
}

(C) MESTE NGO

JEL code: $\mathrm{H} 54$, R41

\begin{abstract}
:
Transportation infrastructure belongs between the most important economic elements of every government. It provides exchange of goods and services, participating by considerable degree on generation of GDP. Every disruption of transportation infrastructure causes financial losses. It paralyses the economy on local, regional or national and transnational level. Road bridges belong to the important elements of transportation infrastructure. Those belonging to highway network or European road network are of especially significant importance. Every damage or disruption of such element results in partial distortion of goods exchange system (truck transport), which damages the economic interests and relations on individual levels of government administration. Possible solution for prevention of, particularly, deliberate attacks on these elements, is their protection. This article contains the proposal of possible approach to protection of road bridge as an element of critical transportation. The approach featured in it is applied to model referential object (protected object) and therefore the data which are used in the proposal have only the illustrational character.
\end{abstract}

\section{Keywords:}

protection, security, transport, critical infrastructure, sector, element, road bridges, referential object, security analysis

\section{INTRODUCTION}

Transportation infrastructure belongs between the national economic pillars of nearly every government. Its significance increases in recent period. Transnational exchange of goods, as well

The address of the corresponding author: Dagmar Vidriková

麦”D Dagmar.Vidrikova@fsi.uniza.sk as the national one gradually re-oriented to road transportation. Every delay caused by malfunction or reduction of functionality of road communications eventually causes, inter alia, also high material damages. Set logistic systems require supply of goods or services in exactly set time. Every delay causes secondary or tertiary harmful consequences. Internationalization of trade cooperation that overreaches the 
framework of national level allows the effectiveness of national economics, but also their disruption. Even several day long service outages, e.g. caused by late delivery, may cause the production to stop, etc. These damages are hardly calculable in current time. For the purpose of securing of fluency in road transportation it is necessary to accept preventive measures to prevent these losses and damages.

In recent period, a new phenomenon arose, with goal of road traffic disruption - terrorism. Its objects of interest contain also international transportation communications. It is possible to include road tunnels and road bridges into this category. These object become potential targets of terroristic attacks because they are freely and uncontrollably available. European Union, as well as its member states, accepts complex measures to fight terrorism. One of these is also protection of those elements that may threaten or disrupt fluency of economic, or threaten human lives and health of the citizens. In general these elements are labelled as critical infrastructure elements. Some of these elements included in the transportation sector are road tunnels and road bridges.

For the purposes of this article, a road bridge (referential object) located on international road network has been selected as a model case of critical infrastructure element. Its economic importance exceeds national level. Possible approach to increase of its level of protection against identified security risks shall be demonstrated on this object.

Following algorithm for creation of security measures proposal to increase protection level of model object shall be applied on this model case:

1. Determination of the context - security analysis of the environment.

2. Risk identification - risk area identification, risk categorization.

3. Risk analysis - determination of probability and consequences, determination of risk degree.

4. Risk evaluation - identification of acceptable and unacceptable risks.

5. Managing the risk - proposal of security measures lowering the unacceptable risks to an acceptable level. (Vidriková \& Boc, 2013)

\section{SECURITY ANALYSIS OF THE REFERENTIAL OBJECT ENVIRONMENT}

The goal of environment security analysis of referential object is to acquire objective information about security environment, based on which it will be possible to identify relevant security risks. It contains systematic process of acquiring, gathering and processing information about those environmental characteristics which constitute the source of security risks and threats to protected referential object.

The subject of environment security analysis of referential object is information about those entities that may, after fulfilment of certain conditions, cause the damaging consequence. Within this security analysis all entities which might have causal relation to the functionality and security of referential object are evaluated. In practice, the environment security analysis consists of search for causal relations and relations between the surroundings and protected referential object. It consists mostly of:

1. description of referential object and identification of assets that would in case of their disruption or destruction significantly unfavourable consequences on the economic and social function of state or region, and consequently on the life quality of its citizens from the viewpoint of protection of their lives, health, security, property, as well as their living environment,

2. external environment analysis - analysis of the surroundings of referential object,

3. internal environment analysis,

4. identification and evaluation of security risks,

5. managing of the security risks - proposal of measures.

\subsection{Description of the referential object model}

The referential object is located in the district town Michalovce in the Košice region by the E50 road. This road leads to Slovak-Ukraine borders (e.g. border crossing Vyšné Nemecké Uzhgorod). It bridges the Zálužice channel. This route is used for the international goods transportation. Average daily intensity is 8137 vehicles, which makes 338 vehicles per hour. Referential object can be placed between 
potential elements of critical infrastructure in the transportation sector, subsector road traffic. In regard to its placement it may be a subject of terroristic attack. Its destruction would limit economic operation of the state and could disrupt the transit function of the state within European Union. No detour is located on the selected transportation segment, which could solve the possible exclusion of the road bridge.

\subsubsection{Basic characteristic of the referential object}

Referential object (hereinafter "bridge object") bridges the urban area of the Michalovce city and crosses the Zálužice channel. The road on bridge object is D 26,5/100 cathegory. Free width of roadway is $2 \times 12 \mathrm{~m}$ on the bridge. The bridge has perpendicular distribution, in the longitudal direction it is in constant gradient. The supporting structure consists of continuous girder. It consists of unicameral cross-section with bridge cantilevers which are supported by prefabricated brace bars. The thickness of the upper slab is 0.5 $\mathrm{m}$. The crossbeams contain openings $1.8 \mathrm{~m}$ wide and $2.4 \mathrm{~m}$ high, allowing the passage through the bridge (the bridge object chamber). The supporting structure crossbeams are preloaded by cables tensioned in pre-stressing - $1320 \mathrm{MPa}$. The roadway is $90 \mathrm{~mm}$ thick bitumen. Monolithic concrete crash barriers $1100 \mathrm{~mm}$ high, class of restraint H3 (STN EN 1317-2) and deformation depth of $1440 \mathrm{~mm}$ are built at the edges of roadway.

Other characteristics of the bridge object (Technická správa)

Single-deck, permanent, immobile road bridge with upper bridge deck

Bridge length: $85 \mathrm{~m}$

Length of the bridge object: $100 \mathrm{~m}$

Obliqueness of the bridge object: $\alpha=100 \mathrm{~g}$

Width between crash barriers: $2 \times 12 \mathrm{~m}$

Width between outermost crash barriers: $27.5 \mathrm{~m}$

Total width of the bridge object: $31 \mathrm{~m}$

Bridge object height: $30.8 \mathrm{~m}$

Overall height: $4.7-6 \mathrm{~m}$

Maximum height of the bridge object: $39.0 \mathrm{~m}$

Maximum height of the bridge object including the pylons: $53.0 \mathrm{~m}$ (Pillar no. 3)

Area of the bridge object: $518 \times 2 \times 11.75=$ $1024.25 \mathrm{~m} 2$

Load of the bridge object: LM 1 according to STN EN 1991-2. (STN EN 1991-2)

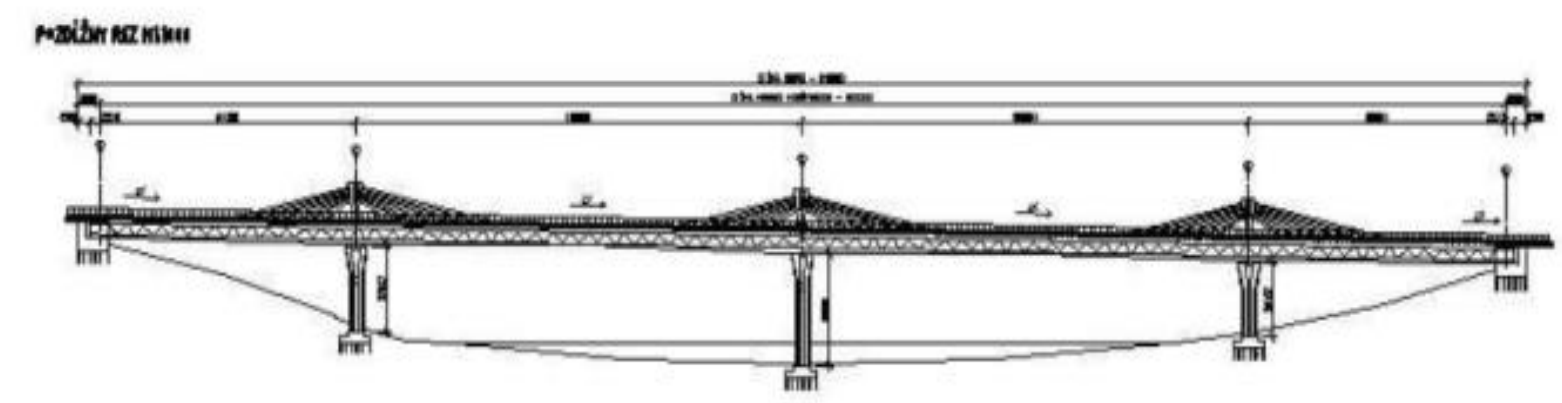

Fig. 1 Side view of the bridge object (Technická správa)

\section{Accessories}

- roadbed - total thickness of the roadbed is $90 \mathrm{~mm}$ (including full isolation), consists of bitumen;

- security devices of bridge object - they consist of concrete wall, which is constraint into bridge deck supporting structure 1100 $\mathrm{mm}$ high over the roadbed; the edges of model bridge object are secured by the concrete barriers in the height of $1100 \mathrm{~mm}$;
- anti-noise measures - are located at both edges of the bridge object on the walls of outer channel grating.

Bridge object is designed in such way that it resists hurricane-grade wind (speed of $110 \mathrm{~km}$ per hour). The weakest places of this object are mainly:

- technical space and

- bridge deck. 


\subsection{Security environment analysis (search for connections)}

Within the security environment analysis the external and internal connections (parameters) are sought. These need to be taken into account in the risk management and determination of security scope and criteria of risks (Belan, 2013), that, when activated, could endanger the protected object.

Security risk encompasses protection of property from the damages caused by the deliberate actions. Security risk is understood as event that could lead to endangerment of the referential object, e.g. by unauthorized intervention into its structure. (STN ISO 31000) (STN 01 0380) (STN EN 31010)

\subsubsection{Analysis of the external security environment (external connections)}

Analysis of the external security environment is carried out for the purpose of assessment of all eligible security risk sources of the bridge object. For the purposes of this article, we consider its immediate surroundings to be the external security environment. Following characteristics of the environment are analysed:

- Geographical.

- Hydrometerological.

- Demographical.

- Criminal.

- Dislocation and structure of the security forces.

Analysis of the listed characteristics is related solely to the potential sources of security risks, which may endanger the referential object and its identified assets.

\subsubsection{Geographical characteristic of the bridge object environment}

The bridge object is located in the Michalovce district. This district is one of the larger districts within the Košice region. It covers area of more than $1000 \mathrm{~km} 2$. It is adjacent to Sobrance district from the eastern side, to Humenné and Vranov nad Toplou districts, that belong to the region of Prešov, the eastern border of the district is also the state border of Ukraine. The Vihorlat Mountains encroach upon the district area from the northern side and the East Slovak Lowland covers most of its area. On the north-east,
Vihorlat Mountains extend, inhibiting the air flow from the north. (www.michalovce.sk/article-msp76, 2013) The Slanské Hills stretch out from the western side. Vihorlat Mountains are of volcanic origin and Vihorlat is their highest peak. Except for the volcanic origin, the mountain range of these mountains is also characterized by potential earthquakes caused by tectonic faults. The city of Michalovce is considered to be the administrative centre of the district.

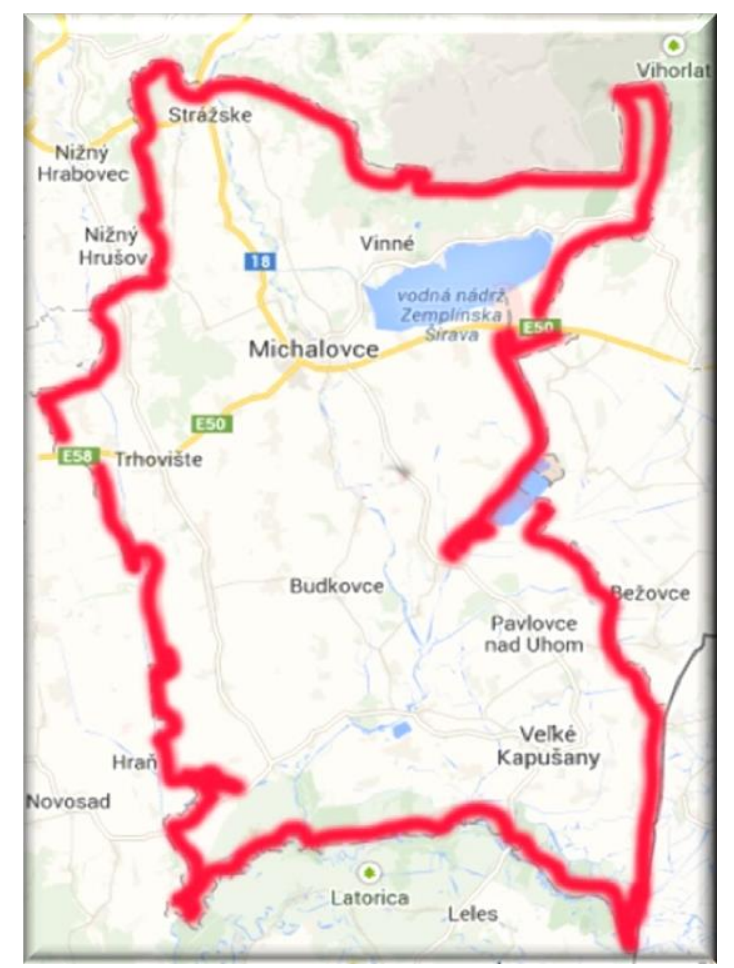

Fig. 2 Michalovce district map (modified by the author according to (https://maps.google.sk, 2013))

\subsubsection{Hydrometeorologic characteristics of the bridge object environment}

The territory of Michalovce is dewatered by the river Laborec, which belongs to the river basin of the river Bodrog (see Figure 3). Rivers Latorica and Bodrog are flowing in this area from Ukraine. The territory has insufficient slope to provide enough drainage for surface waters and prevent regular floods. Despite the conducted treatment of watercourses, yearly flood occur. The river basin of rivers Ondava and Laborec belong to the most hazardous rivers. (www.michalovce.sk/article-msp-76, 2013)

Security environment of the bridge object is, when taking into account the hydrometeorology, 


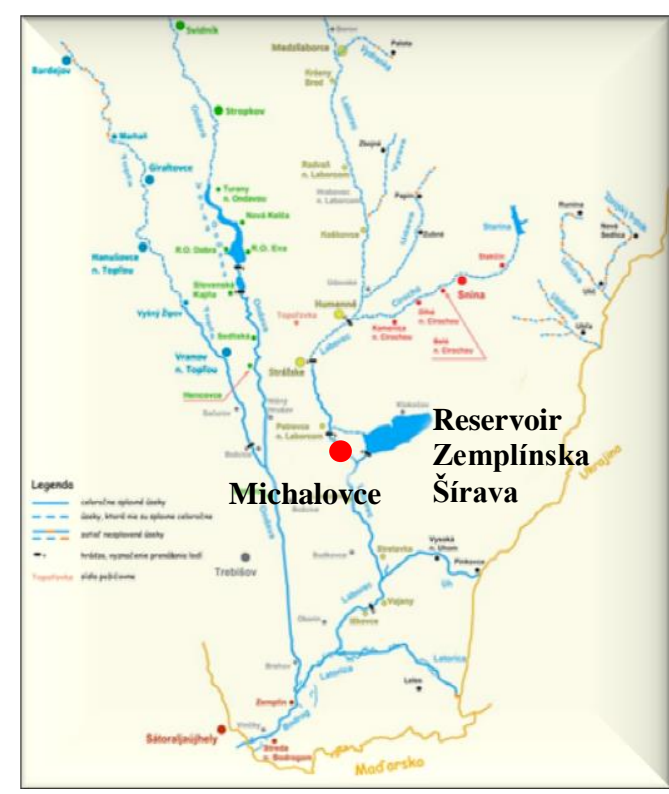

Fig. 3 Bodrog river basin (modified by the author according to (http://www.alcea.sk/rieky-regionu.html, 2013))

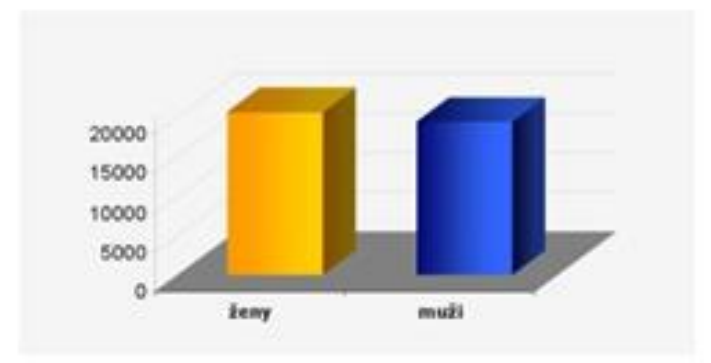

men - 19275

women - 20536

threatened by torrential rain and storms, which in turn cause the floods and landslides related to them. (www.michalovce.sk/article-msp-76, 2013) Reservoir Zemplínska Šírava is located in the vicinity of Michalovce. In 2000, a flood situation occurred, in which centenarian water level was exceeded on the river Bodrog (Figure 3).

\subsubsection{Demographic characteristic of the bridge object environment}

Population of Michalovce district was 110897 in year 2011. The district consists of 75 municipalities and of cities Michalovce, Strážske a Vel'ké Kapušany. The population consists mainly of citizens of Slovak, Romani and Hungarian nationality, with average age of 37.25 years. The Roma living in settlements are carriers of the indebtedness, low education level, unemployment or criminality. (Rokovania vlády Slovenskej republiky, 2013)

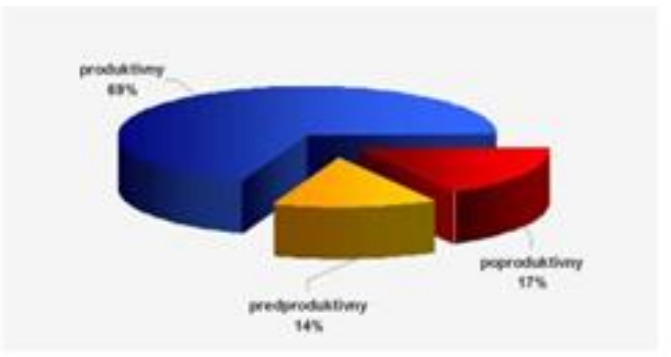

Age structure of population
preproductive $(0-14)-5536$
productive $(15-60)-27404$
post-productive $(>60)-6871$

nvironment (modified by the author according Fig. 4 Population demographics of the Michalovce city environment (mo
to (http://www.michalovce.sk, 2013))

Table 1. Unemployment progress in Michalovce city in years 2008 - 2011 (modified by the author according to (http://www. michalovce.sk, 2013))

\begin{tabular}{|l|l|l|l|l|}
\hline Unemployed & $\mathbf{2 0 0 8}$ & $\mathbf{2 0 0 9}$ & $\mathbf{2 0 1 0}$ & $\mathbf{2 0 1 1}$ \\
\hline Men & 1061 & 1525 & 1492 & 1542 \\
\hline Woman & 983 & 1314 & 1331 & 1416 \\
\hline Total unemployment & $\mathbf{3 4 6 9}$ & $\mathbf{2 9 0 9}$ & $\mathbf{2 4 9 0}$ & $\mathbf{2 0 6 4}$ \\
\hline Registered unemployment rate (\%) & 7,71 & 10,71 & 10,49 & 11,47 \\
\hline
\end{tabular}

Unemployed persons count in 2011 reached in the Michalovce district the number of 8647 persons, what represents $19.40 \%$. Directly in the city it reaches $11.47 \%$ (Figure 5-6).
Most of the applicants for employment within the Michalovce district (as well as in the Michalovce city) finished secondary vocational education at the secondary vocational school (district - 2995, city - 818 persons) and the second most prominent group was the persons who finished 
Vidrikova, Boc \& Škatuliakova. Possible approach to CIP in transport sector

MEST Journal Vol.2 No.1 pp.103-115

elementary or secondary education (district - 288 wage in year 2011 reached $786 €$. (Rokovania persons, and city - 552291 persons). The gross vlády Slovenskej republiky, 2013)

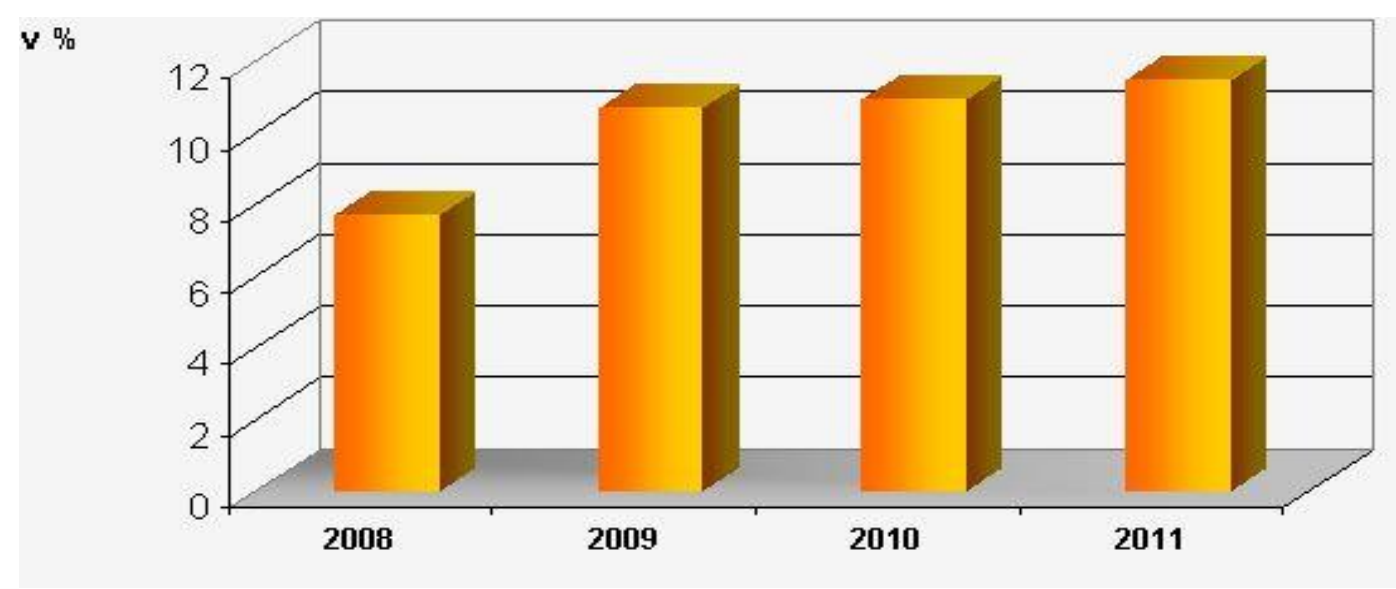

Fig. 5. Development dynamics of the unemployment in Michalovce city in years 20082011. (modified by the author according to (http://www.michalovce.sk, 2013))

Table 2. Structure of the unemployment according to the level of achieved education (modified by the author according to (http://www.michalovce.sk, 2013))

\begin{tabular}{|l|r|r|r|r|}
\hline \multicolumn{1}{|c|}{ Education } & $\mathbf{2 0 0 8}$ & $\mathbf{2 0 0 9}$ & $\mathbf{2 0 1 0}$ & $\mathbf{2 0 1 1}$ \\
\hline 0 - no education & 121 & 130 & 155 & 138 \\
\hline 1 - elementary education & 382 & 432 & 417 & 418 \\
\hline 2 - secondary vocational school trained & 584 & 871 & 779 & 818 \\
\hline 3 - secondary vocational school without graduation & 7 & 3 & 4 & 4 \\
\hline 4 - secondary vocational school with graduation & 227 & 332 & 322 & 365 \\
\hline 5 - secondary grammar school & 97 & 134 & 158 & 167 \\
\hline 6 - secondary technical school & 468 & 678 & 677 & 686 \\
\hline 7 - higher secondary education & 19 & 44 & 72 & 82 \\
\hline 8 - university & 139 & 214 & 236 & 277 \\
\hline 9 - scientific education & 0 & 1 & 3 & 3 \\
\hline Total number of recorded unemployed persons & $\mathbf{2 0 4 4}$ & $\mathbf{2 8 3 9}$ & $\mathbf{2 8 2 3}$ & $\mathbf{2 9 5 8}$ \\
\hline
\end{tabular}

\subsubsection{Crime}

Crime activities in Michalovce district are shown in table 3.

Table 3. General criminality in the Michalovce district in 2012 (modified by the author according to (http://www.minv.sk, 2013))

\begin{tabular}{|l|c|c|}
\hline \multicolumn{3}{|c|}{ General crime activity in year $\mathbf{2 0 1 2}$} \\
\hline \hline $\begin{array}{c}\text { Type/region - } \\
\text { district }\end{array}$ & $\begin{array}{c}\text { Michalovce } \\
\text { district }\end{array}$ & $\begin{array}{c}\text { Košice } \\
\text { region }\end{array}$ \\
\hline Property & 861 & 6620 \\
\hline Vice & 37 & 187 \\
\hline Violent & 141 & 1157 \\
\hline Other & 283 & 1466 \\
\hline Overall & 1322 & 9430 \\
\hline
\end{tabular}

The dominant type of crime in the external environment of the bridge object in 2012 was mainly the property crime. Especially the crimes connected with theft of metals increased. Bridge object may thusly become a potential target mainly for of the perpetrators of this crime activity (individual metal parts - ropes, retaining safety devices, etc.). Possibility of other unlawful activities (e.g. terroristic attack) is not affected by this statement, despite the fact, that this kind of criminal activities has not been registered or detected in the analysed environmental surroundings of the referential object.

\subsubsection{Structure of the security forces}

Structure of the security forces in the area of bridge object consists of: 
- District head office of the Police Force, which resides circa $2 \mathrm{~km}$ from the bridge object. Arrival of the Police Force members to the bridge object for the purposes of intervention is 4 minutes.

- Municipal Police has 26 members and 6 employees. Its distance from the bridge object is $3.1 \mathrm{~km}$. Intervention is possible within 5 minutes. (www.michalovce.sk/articlemsp-76, 2013)

- Private security services - 11 companies operate within the concerned environment. The concentration of their locations of residence allows the intervention units to execute their intervention in time between 5 and 10 minutes.

\subsubsection{Analysis of the internal security environment (internal connections)}

Analysis of the internal security environment is focused on the existing status of the security of the bridge object, especially of its assets (technical spaces, bridge deck). Existing security measures and their effectiveness (especially for the mechanical means of protection, electronic security signalling, organizational or regime measures, etc.) are analysed in the next part. In this case, technical spaces and bridge deck are analysed.

\subsubsection{Technical space (overpass chamber)}

Entry into the overpass chamber is secured by a single main entrance. This entrance is protected by steel door. Door has size of $800 \times 1970 \mathrm{~mm}$ and is of the security class 3 . They are able to resist attacks of vandals and force of $3 \mathrm{kN}$ exerted on point and to resist static load of $6 \mathrm{kN}$ and attack with crowbar of length up to $710 \mathrm{~mm}$. The door is protected from opening by a construction lock with cylinder housing that protects it against its breaking. No active protection elements are used for securing of the chamber. (Technická správa)

\subsubsection{Bridge deck}

Bridge deck is freely accessible. Overview of the vehicles or other traffic participants is not provided. It is illuminated at night. By the edge of bridge deck are placed the barriers, which protect its edges.

\subsubsection{Partial conclusion}

Physical protection of the object is not executed. Only visual control of technological space and bridge deck is carried out on regular basis (twice a year). The administrator has no regime or organizational measures drawn up for protection of object. No documentation is created, which would adjust the procedures after detection of security incident or if there is suspicion of possible intrusion into object. It is necessary to assess the security of the model object from the viewpoint of existence of the internal security risks.

\subsection{Identification of security risks}

Following security risks threatening the assets of the bridge object were identified on the basis of security analysis of its internal and external environment:

1. External security risks influencing both identified assets:

a) Natural risks:

- floods - caused by the gradient of the area,

- landslide as the result of floods and instability of the geologic bedrock (disruption of static of the whole object),

- flood wave caused by rupture of the water dam Zemplínska Šírava, with pressure of 96 $\mathrm{kN}(9600 \mathrm{~kg})$ it may cause total disruption of the object's statics - especially the supporting pillars,

- earthquake caused by tectonic failures could disrupt the statics of the bridge object,

- critically low temperatures - may influence negatively the traffic on the bridge object, which creates precondition for chain road accidents and the secondary result is negative influence on the condition of bridge deck, as well as the supporting pillars,

- tempest - road accident may be caused due to high speed of the wind, especially with the TIR vehicles transporting substances included into the category ADR (e.g. chain road accident - damage to bridge deck and its components).

b) Social (criminal) risks

- criminal activities of property character theft of metal materials - disruption of the object statics, removal of mechanical means 
of protection that secure the overpass chamber and creation of conditions for further antisocial activities,

- terrorism - utilization of the explosive devices may cause disruption of bridge deck, supporting pillars or other construction parts of the object, which may in significant way disrupt the road traffic indefinitely,

- traffic accident - mainly of the vehicles that transport material classified into category ADR (whether intentional or by negligence).

2. Internal security risks that influence both assets:

a) Technical risks

- material fatigue - degradation process of irreversible changes of characteristics and status changed by fatigue of the construction materials developed by its repeated mechanical, thermal, or thermomechanical loading with simultaneous interaction of other factors induced by oscillatory (cyclical) loading. Highly stressed parts of the bridge construction in whole cross-section or in place of tension concentration are often disrupted by the cyclicity fatigue, mainly with relatively negligible amplitudes of loading and nearly immeasurable amplitudes of plastic deformation,

- fatigue break - if the fatigue strength is exceeded, in the place within the bridge deck or pillar, where the tension concentration occurs, may originate a breach after certain number of cycles, and this may gradually spread into the depth of material. This diminishes the supporting cross-section of the component up to the moment when the tensions induced by immediate loading exceed the fatigue strength and static breach originates in the remaining cross-section,

- fatigue lifetime - the change of the mechanical characteristics of the bridge deck, pillar, or overpass chamber may cause gradual nucleation and spreading of the breaches, which will culminate into final sudden breach, without former macrodeformation of the concerned assets material. This may significantly weaken the supporting cross-section of bridge deck, as well as other parts of the object. b) Social (criminal) risks:

- criminal activities of the property character theft of the metal materials by internal employee of the object administrator disruption of the object statics, removal of mechanical means of protection that provide security of overpass chamber and creation of conditions for further antisocial activities,

- terrorism - internal perpetrator, motivated by different incentives (dissatisfaction with financial remuneration, revenge, inability to cope with discharge, etc.) utilizing explosive devices may intentionally disrupt the compatibility and stability of the bridge deck, supporting pillars and other construction parts of the object, which may in significant way disrupt the road traffic indefinitely if the risk activates,

- sabotage - intentional conduct of the object administrator's employee may in the form of damage to object's integrity for the purpose of disruption or obstruction of its utilization (failure to perform the control activities, biased evaluation of existing status, unreported fatigue change of supporting parts of the project, etc.),

- leak of information of technical character caused by employee, may expose the weak points of the model referential object.

\subsection{Risk evaluation}

Risks that may threaten the model road bridge and thusly cause its partial or total disruption were identified by the analysis of connections. These risks are expressed in the risk registry (Table 4). Identified risks were classified according to their severity. Their assessment was based on the mathematical model of risk:

$\mathbf{R}=\mathbf{P} \times \mathbf{C}$

where $\mathrm{R}$-risk,

$\mathrm{P}$ - probability of its occurrence,

C - consequence (It is necessary to determine the probability of the risk occurence as well as the consequence by qualitative or quantitative methods. For the purpose of this article this step has been left out). 
Table 4. Registry of the identified security risks (authors)

\begin{tabular}{|c|c|c|c|c|c|c|}
\hline Risk sphere & Risk type & Form of expression & Causes, sources & $\mathbf{P}$ & C & $\mathrm{R}$ \\
\hline \multirow{5}{*}{$\begin{array}{l}\text { Internal security } \\
\text { risks }\end{array}$} & \multirow{4}{*}{ Social risks } & $\begin{array}{l}\text { Terrorism } \\
\text { (bridge deck, } \\
\text { chamber) }\end{array}$ & $\begin{array}{l}\text { Dissatisfaction of } \\
\text { the employee }\end{array}$ & 3 & 4 & VH \\
\hline & & $\begin{array}{l}\text { Theft of material } \\
\text { (bridge deck, } \\
\text { chamber) }\end{array}$ & Enrichment & 3 & 3 & H \\
\hline & & $\begin{array}{l}\text { Information leak of } \\
\text { technical character }\end{array}$ & $\begin{array}{l}\text { Dissatisfaction of } \\
\text { the employee }\end{array}$ & 3 & 3 & H \\
\hline & & $\begin{array}{c}\text { Sabotage - } \\
\text { insufficient control } \\
\text { activity }\end{array}$ & $\begin{array}{l}\text { Not reacting to } \\
\text { detected failures }\end{array}$ & 2 & 3 & $\mathbf{M}$ \\
\hline & Technical risks & $\begin{array}{l}\text { Material fatigue } \\
\text { (bridge deck, } \\
\text { chamber) }\end{array}$ & $\begin{array}{l}\text { Not reacting to } \\
\text { detected failures }\end{array}$ & 2 & 3 & $\mathbf{M}$ \\
\hline \multirow{8}{*}{$\begin{array}{l}\text { External security } \\
\text { risks }\end{array}$} & \multirow{3}{*}{ Social risks } & $\begin{array}{l}\text { Theft of material } \\
\text { (bridge deck, } \\
\text { chamber) }\end{array}$ & Enrichment & 3 & 2 & H \\
\hline & & Terrorism & Terroristic attack & 2 & 5 & VH \\
\hline & & Traffic accident & Negligence & 4 & 3 & H \\
\hline & \multirow{5}{*}{ Natural risks } & Flood wave & Dam rupture & 2 & 5 & VH \\
\hline & & Earthquake & Tectonic failures & 3 & 2 & $\mathbf{M}$ \\
\hline & & Tempest & Climate & 4 & 1 & $\mathbf{M}$ \\
\hline & & $\begin{array}{l}\text { Overspill of Laborec } \\
\text { river }\end{array}$ & Torrential rain & 4 & 4 & VH \\
\hline & & $\begin{array}{l}\text { Critically low } \\
\text { temperatures }\end{array}$ & Climate & 4 & 1 & $\mathbf{M}$ \\
\hline
\end{tabular}

L- low risk, $\mathrm{M}$ - medium risk, $\mathrm{H}$ - high risk, $\mathrm{VH}$ - very high risk.

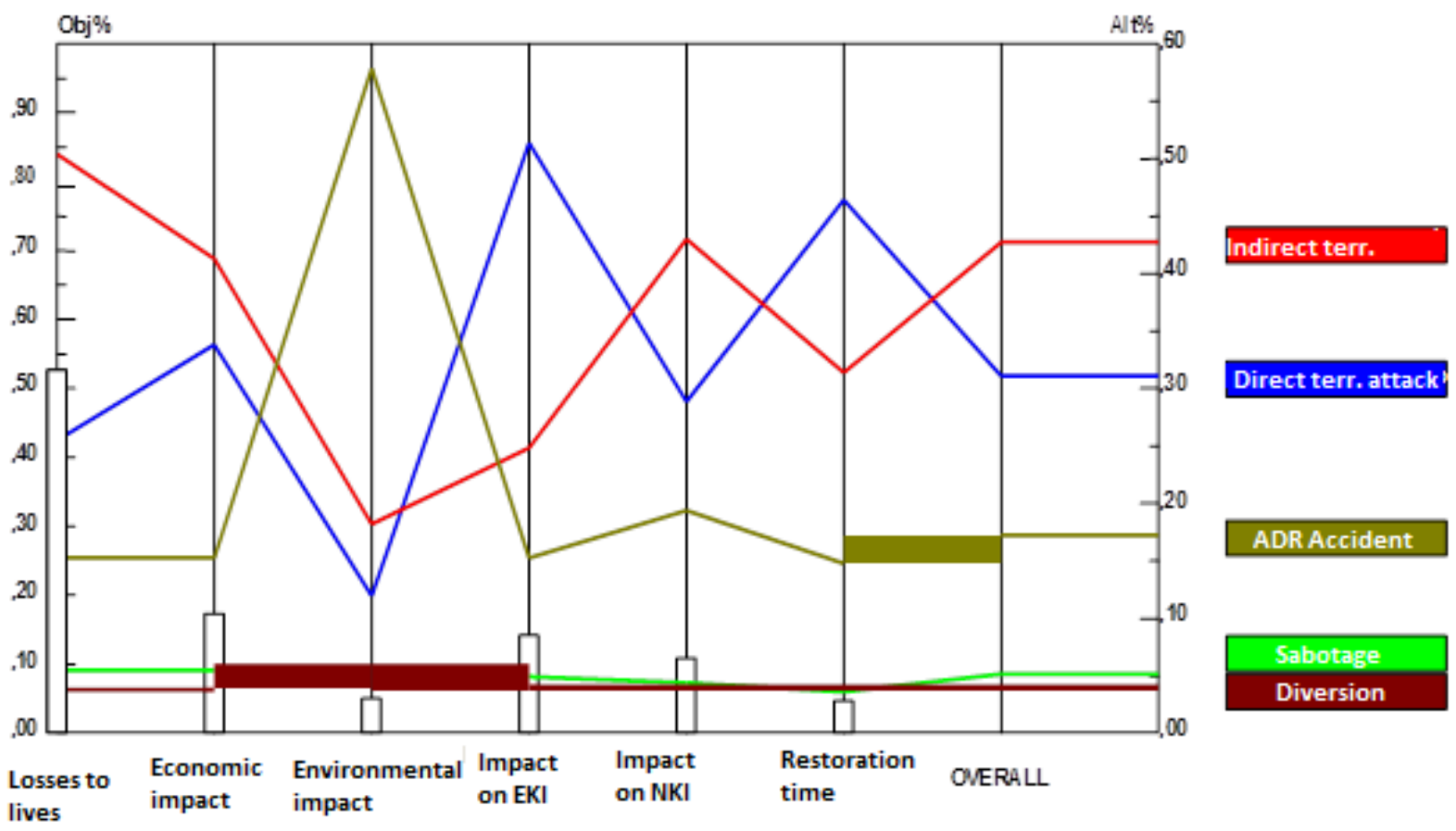

Fig. 6. Evaluation of the security risk severity (authors) 
Severity evaluation of the security risks was assessed with the use of hierarchic process analysis (Figure 6). The criterion of evaluation and subsequent acceptability were the consequences, such as:

- losses to lives,

- economic impact,

- impact on foreign trade within EU,

- impact on national economy,

- damage to the environment,

- length of restoration.

Based on the hierarchic process analysis, following security risks were prioritized according to their severity:

1. Direct terroristic attack $(A)$ - may be carried out in the supporting construction, by placing the explosive system into the overpass chamber, which would cause significant damage to the bridge gap, as well as the exclusion of usability of the model referential object for its purpose - that may cause significant economic losses, as well as losses to the lives and damage to health of persons located in that time on the bridge deck or near the object

2. Indirect terroristic attack $(B)$ - related to execution of terroristic attack on the water dam Zemplínska Šírava. Deliberate damage to the dam would cause flooding of the road bridge, as well as the whole surrounding.

3. Enrichment $(C)$ - theft of the material.

4. Sabotage (D) - criminal activity of the employees.

5. ADR Accident (E) - transportation of dangerous substances and subsequent accident originating during the transportation could damage the bridge deck and could influence the environment depending on the type of the transported substance.

Significance of individual risks was determined on the basis of the hierarchic processes analysis. Included between the risks with the greatest consequences are indirect terroristic attack, direct terroristic attack, accident during transportation of dangerous substances, sabotage and diversion.

\subsection{Security risks management}

The process of risk management consists mainly of the selection of the way the risk will be manipulated. The selection of way is the search for optimal solution. It has to be a compromise between costs and effort, which will be expended for its realization, and the benefits of the selected variant of risk management.

The risk management methods are mainly the following:

- risk avoidance,

- acceptance or increase of the risk for the purpose of achievement and exploitation of the opportunity, removal of the risk source, change of the probability of risk occurrence, change of the consequence magnitude, sharing of the risk with other subjects, maintaining of the risk on the basis of informed decision. (STN ISO 31000)

The method of managing the assessed and prioritized security risks in the case of model bridge object is the change of the consequence magnitude. For its achievement, whole complex system of security precautions (integrated security system - ISS) shall be realized. ISS consists of the following elements:

- mechanical security systems,

- physical protection, - alarm security systems,

- organizational and regime measures.

\section{PROPOSAL OF THE SECURITY PLAN FOR PROTECTION OF MODEL CRITICAL INFRASTRUCTURE ELEMENT}

The designing of the variants of security plan for protection of model critical infrastructure element shall be based on the character and consequences of potential threat, the result of the initiation of security risk and its consequences.

\subsection{Proposal of the Standard Security}

Security plan shall consist of the security measure proposals that decrease the consequences of the identified and prioritized risks. The basic task during the design of the individual security plan variants shall be to decrease the level of external and internal security risks to the acceptable level. The standard variant is referred to only for illustration (sub-chapters 3.2 and 3.3). 
3.2 Securing of the external and internal environment from terroristic attack, sabotage or diversion

Protection of the external surroundings of the model referential object:
External surroundings of the model referential object shall be monitored by surveillance system $180^{\circ}$ (Figures 7 and 8) with infrared reflectors. The video signal shall have its output at the alarm receiving centre of the Municipal Police in Michalovce. This surveillance system shall constantly monitor the set area.
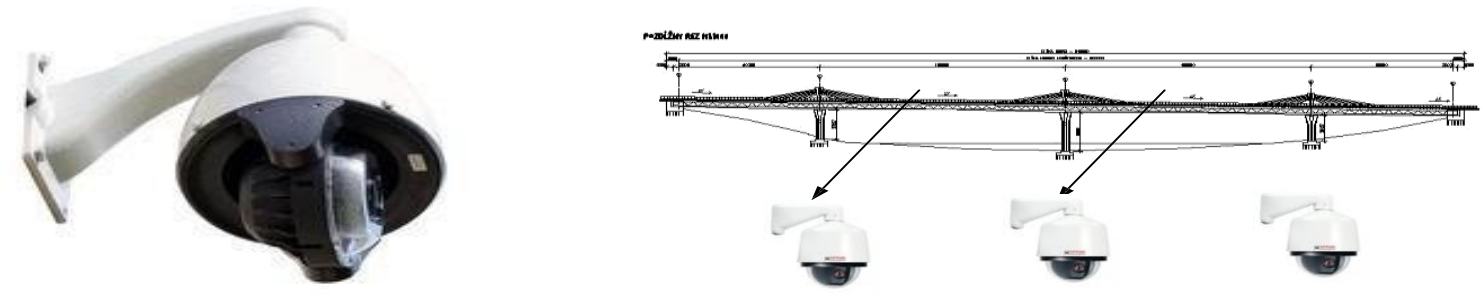

Fig. 7. and 8. CCTV $180^{\circ}$ with IR reflector

Protection of the internal environment:

Entry door to the overpass chamber are to be completed by independent resistance class 3 security locks. (STN EN 1627) The door hinges shall be protected against their removal. Internal entry space into the supporting construction shall be completed by installation of movement

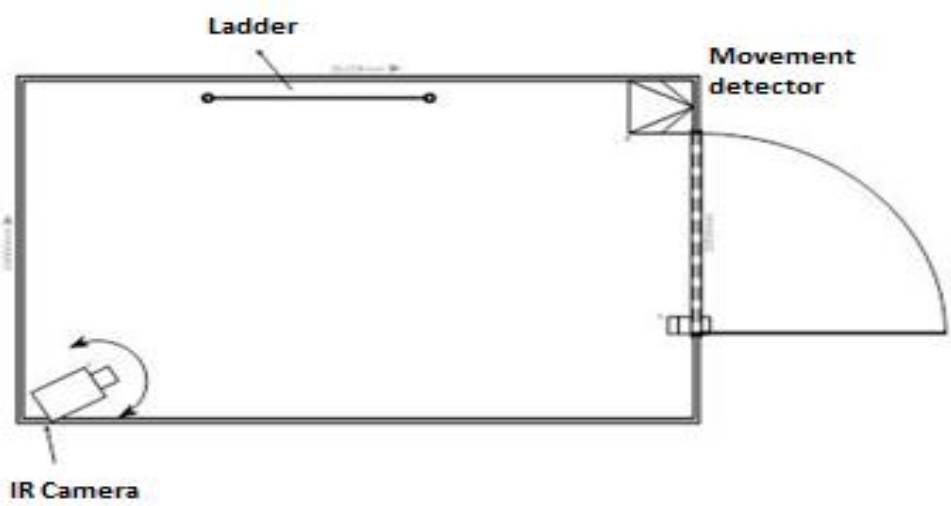

Fig. 9. Means for securing of entry into the supporting construction

Concrete shields (breakwaters), shall be installed on individual pillars of the model referential object in the height of the flood wave. These could detector with IR camera system (Figure 11), fire detector, as well as the shock detector, which will be connected to the alarm receiving centre of the Municipal Police in Michalovce (ARC McP). After intrusion into the supporting construction the image shall be sent into the control room and subsequently to the external sirens.

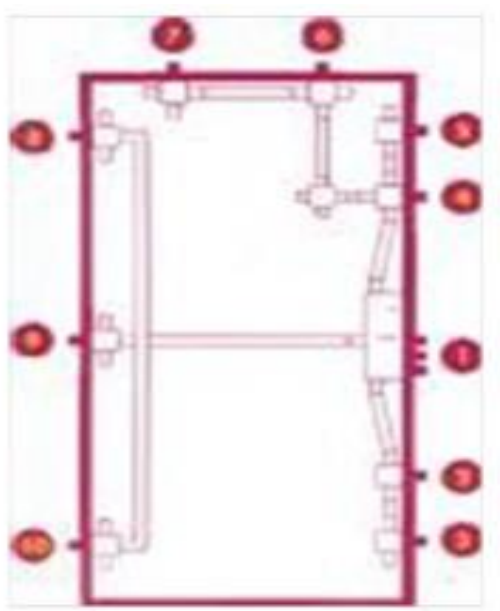

Fig. 10. Illustration of point security (authors)

protect the bridge pillars from damage or disruption of statics by flood wave in case of terroristic attack on the Zemplínska Šírava dam. 


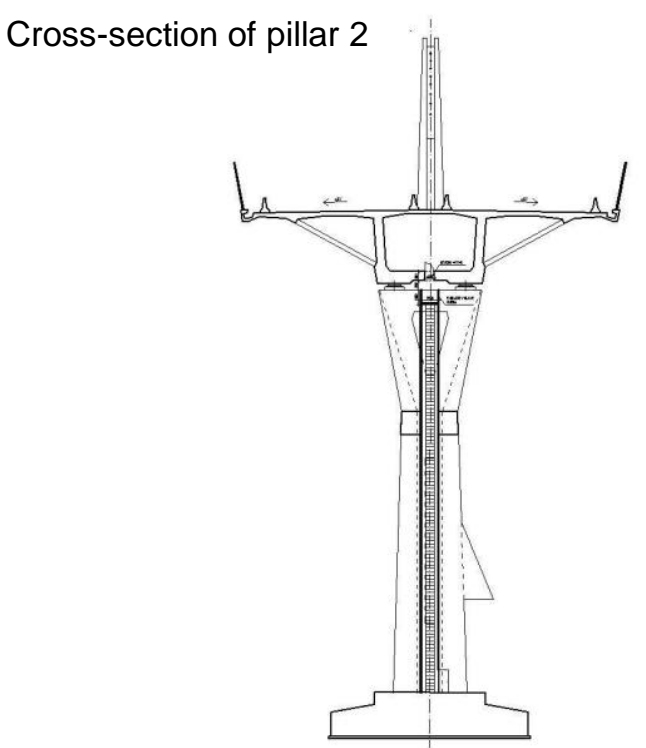

Fig. 11. Cross-section by pillar with a breakwater (Technická správa)

\subsection{Securing of the model road bridge deck}

Securing of the bridge deck from damage will be possible by lowering the maximum allowed speed of vehicles to $60 \mathrm{~km} / \mathrm{h}$ and by installation of CCTV system connected to the ARC McP. Supervision by members of the Police force shall be carried out irregularly in this segment. (Figure 12).

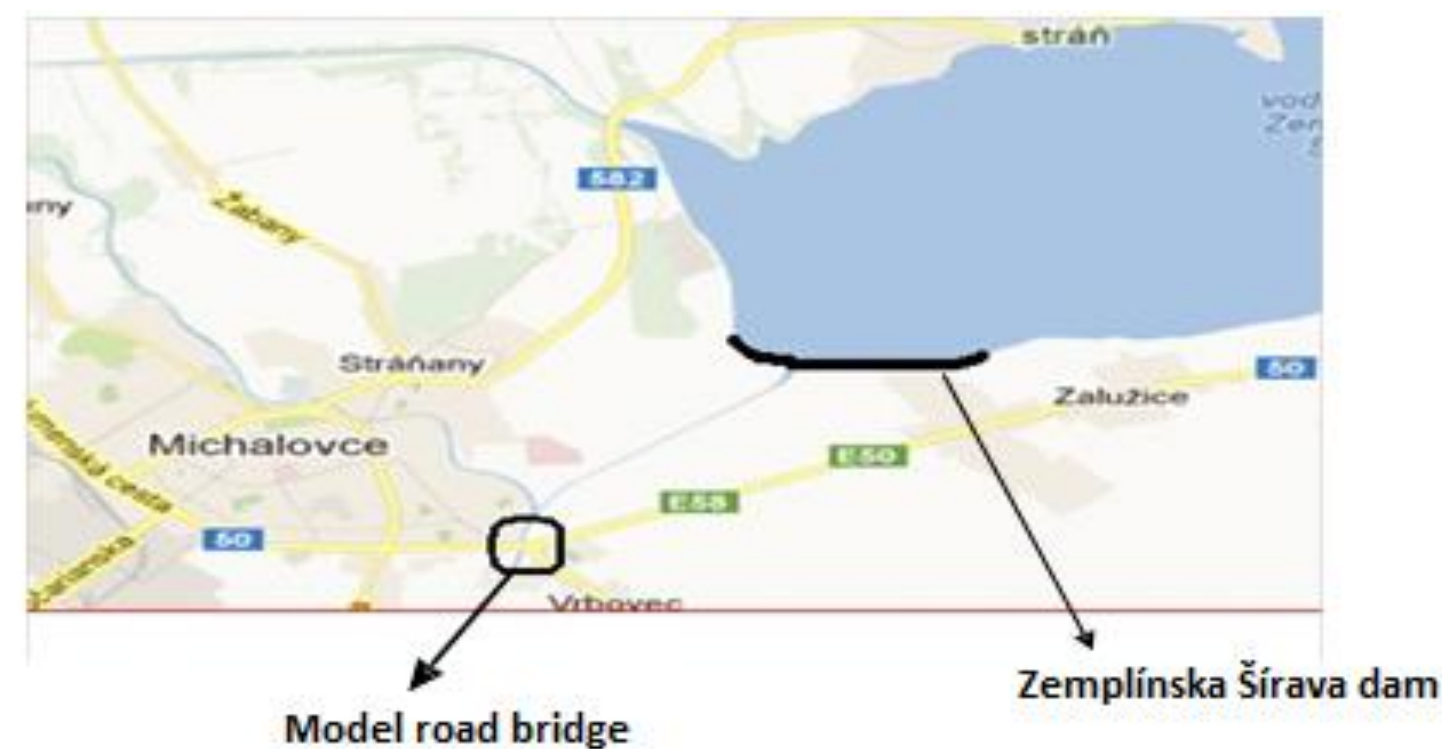

Fig. 12. Depiction of the location of model road bridge and Zemplínska Širava dam (Wikimapia. Zemplínska Šírava., 2013http://wikimapia.org)

\section{CONCLUSIONS}

Goal of this article was to outline an algorithm for design of protection plan for element of critical infrastructure. The proposed algorithm accepts the valid technical standards that regulate the security risk management as well as the requirements of legislation (e.g. Act no. 45/2001
Coll. on protection of critical infrastructure). When designing specific elements of the ISS, especially during selection of mechanical means of protection and alarm intrusion systems, it is necessary to follow the valid technical standards that regulate the security classes of the proposed elements, or, respectively, the breach resistance classes. 


\section{WORKS CITED}

http://www.alcea.sk/rieky-regionu.html. (2013).

http://www.michalovce.sk. (2013).

http://www.minv.sk. (2013).

https://maps.google.sk. (2013).

Rokovania vlády Slovenskej republiky. (2013). Retrieved from http://www.rokovania.sk

www.michalovce.sk/article-msp-76. (2013).

Wikimapia. Zemplínska Širava. (2013http://wikimapia.org).

Belan, L'. (2013). Prednášky z predmetu bezpečnostný manažment.

STN 01 0380. (n.d.). Manažérstvo rizika (AS/NZS 4360:1999).

STN EN 1317-2. (n.d.). Záchytné bezpečnostné zariadenia na pozemných komunikáciách. Čast' 2: Výkonnostné triedy, prebracie kritériá na nárazové skúšky a skúšobné metódy pre zvodidlá vrátane zábradl'ových zvodidiel.

STN EN 1627. (n.d.). Dvere, okná, závesné steny, mreže a uzávery. Odolnost' proti vlámaniu. Požiadavky a triedenie.

STN EN 1991-2. (n.d.). Eurokód 1. Zat'aženia konštrukcií. Čast' 2: Zat'aženia mostov dopravou.

STN EN 31010. (n.d.). Manažérstvo rizika. Technicky posúdenia rizika.

STN ISO 31000. (n.d.). Manažérstvo rizika - Zásady a návod.

Technická správa. (n.d.). Most na dial'nici mestská estakáda DCI, Nosná konštrukcia a príslušenstvo.

Vidriková, D., \& Boc, K. (2013). Ochrana kritickej infraštruktúry I. čast'. Žilinská univerzita.

\section{This work was supported by the Slovak Research and Development Agency under the} contract No. APVV - 0471 - 10

Received for publication:

Revision received:

Accepted for publication:
15.10 .2013

28.11.2013

21.12.2013

\section{How to cite this article?}

Style - APA Sixth Edition:

Vidrikova, D., Boc, K., \& Škatulikova, K. (2014, 01 15). Possible approach to protection of critical infrastructure element in transport sector. (Z. Čekerevac, Ed.) MEST Journal, 2(1), 103-115. doi:10.12709/mest.02.02.01.11

Style - Chicago Fifteenth Edition:

Vidrikova, Dagmar, Kamil Boc, and Katarina Škatulikova. "Possible approach to protection of critical infrastructure element in transport sector." Edited by Zoran Čekerevac. MEST Journal (MESTE) 2, no. 1 (01 2014): 103-115.

Style - GOST Name Sort:

Vidrikova Dagmar, Boc Kamil and Škatulikova Katarina Possible approach to protection of critical infrastructure element in transport sector [Journal] = Possible approach to CIP element in transport sector // MEST Journal / ed. Čekerevac Zoran. - Belgrade : MESTE, 01 15, 2014. - 1 : Vol. 2. - pp. 103-115. - ISSN 2334-7058 (Online); ISSN 2334-7171.

Style - Harvard Anglia:

Vidrikova, D., Boc, K. \& Škatulikova, K., 2014. Possible approach to protection of critical infrastructure element in transport sector. MEST Journal, 15 01, 2(1), pp. 103-115.

Style - ISO 690 Numerical Reference:

Possible approach to protection of critical infrastructure element in transport sector. Vidrikova, Dagmar, Boc, Kamil and Škatulikova, Katarina. [ed.] Zoran Čekerevac. 1, Belgrade : MESTE, 01 15, 2014, MEST Journal, Vol. 2, pp. 103-115. ISSN 2334-7058 (Online); ISSN 2334-7171. 